Volume 12

Number 12012

Article 2

December 2012

\title{
Marriage Without Procreation? A Biblical Analysis
}

Melinda M. Vasser

Cedarville University, mvasser@cedarville.edu

DigitalCommons@Cedarville provides a publication platform for fully open access journals, which means that all articles are available on the Internet to all users immediately upon publication. However, the opinions and sentiments expressed by the authors of articles published in our journals do not necessarily indicate the endorsement or reflect the views of DigitalCommons@Cedarville, the Centennial Library, or Cedarville University and its employees. The authors are solely responsible for the content of their work. Please address questions to dc@cedarville.edu.

\section{Recommended Citation}

Vasser, Melinda M. (2012) "Marriage Without Procreation? A Biblical Analysis," CedarEthics: A Journal of Critical Thinking in Bioethics: Vol. 12 : No. 1 , Article 2. 


\title{
Marriage Without Procreation? A Biblical Analysis
}

Browse the contents of this issue of CedarEthics: A Journal of Critical Thinking in Bioethics.

\begin{abstract}
Children are a gift from God. Psalm 127:3 says, "Behold, children are a heritage from the LORD, The fruit of the womb is a reward" (NKJV). They are not only a gift, but a natural result of the sexual expression of marriage. This naturalness is reinforced by God's command to Adam and Eve to procreate (Genesis 1:28). Because of the value of children and the mandate given to the first parents, it is no surprise that marriage and procreation are tightly linked. Many believe it is wrong for fertile couples to never have children. However, an analysis of the purpose of marriage, natural law, and the biblical evidence suggests that though marriage as a general principle ought to lead to procreation, it is not morally wrong for married couples to never have children.
\end{abstract}

\section{Keywords}

Marriage, procreation

\section{Creative Commons License}

\section{(c) (1) $\Theta$}

This work is licensed under a Creative Commons Attribution-Noncommercial-No Derivative Works 3.0 License.

Follow this and additional works at: http:// digitalcommons.cedarville.edu/cedarethics

Part of the Bioethics and Medical Ethics Commons 


\title{
Marriage Without Procreation? A Biblical Analysis
}

\author{
Mindy Vasser \\ Cedarville University
}

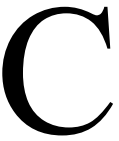
hildren are a gift from God. Psalm 127:3 says, "Behold, children are a heritage from the LORD, The fruit of the womb is a reward" (NKJV). They are not only a gift, but a natural result of the sexual expression of marriage. This naturalness is reinforced by God's command to Adam and Eve to procreate (Genesis 1:28). Because of the value of children and the mandate given to the first parents, it is no surprise that marriage and procreation are tightly linked. Many believe it is wrong for fertile couples to never have children. However, an analysis of the purpose of marriage, natural law, and the biblical evidence suggests that though marriage as a general principle ought to lead to procreation, it is not morally wrong for married couples to never have children.
\end{abstract}

Historically, procreation has been a central, if not the central, purpose for marriage. Justin Martyr of the second century felt that the desire to procreate was the only thing that legitimized sex even for married couples (Haas et al., 2001). The Book of Common Prayer says marriage is meant to bring children (Watters \& Watters, 2009). The Catholic Church has historically rejected birth control, and continues to this day to have strong reservations against it (Sullivan, 2012). The link between marriage and children led John Rice to say, "Those who marry owe a duty to God, a duty to civilization, a duty to their mates and to themselves to bring children into this world and to rear them for God" (1946, p.146).

However, though procreation is an undeniable purpose of marriage and sex in general, it is not the only purpose. Köstenberger (2010) lists procreation as a purpose for sex, but he goes on to mention the relational aspects. He also praises marriage because it allows an acceptable expression of natural sexual desires. Furthermore, he believes these sexual desires and pleasures are not wrong, but rather "the ultimate physical expression of deep, committed, and devoted love" (p.82). Marriage allows two people who truly love and care for each other to wholly give themselves to each other and become "one flesh" (Genesis 2:24). This unity is achieved with or without children and provides the opportunity for two people to serve God together as one unit.

One of the strongest reasons procreation has been viewed as mandatory is because of natural law. Children are a natural result of sex. However, just because something is natural does not always mean it is required. For instance, sex within marriage is a natural, God-ordained event. Nevertheless, Paul in 1 Corinthians 7 not only allows, but encourages people to forgo marriage under certain circumstances, hence encouraging them to suppress their natural sexual desires. Therefore, natural cannot always equal mandatory.

Invoking Scripture does raise the question, however, of the creation mandate found in Genesis 1:28, where God not only tells Adam and Eve to rule the earth, but also to "be fruitful and multiply." However, while the command to rule the earth is applicable to all humanity, the 
command to be fruitful was specific to Adam and Eve. Support for this is found in Genesis 1:26:

Then God said, "Let Us make man in Our image, according to Our likeness; let them have dominion over the fish of the sea, over the birds of the air, and over the cattle, over all the earth and over every creeping thing that creeps on the earth." So God created man in His own image; in the image of God He created him; male and female He created them.

In this passage, the triune God declares that man is to rule God's creation. However, He says nothing about procreation. It is only when he speaks directly to Adam and Eve that he adds the new command for Adam and Eve to multiply.

Furthermore, if God intended everyone to be fruitful, then everyone would have to have children. If everyone were to have children in a manner honoring to God, everyone would have to marry. The apostle Paul expressly states that not everyone must get married. Therefore, not everyone has to be fruitful. Why should this not apply to couples as well as singles?

Paul's reasoning against marriage is that a spouse may distract a person from focusing more on God (1 Corinthians 7:32-34). It is logical to assume that in some cases, children may also serve to take a couple's focus away from God and the life He has called them to live together. Some may wonder why Paul never spoke specifically on this matter, but given the culture of the time, it is unlikely that married couples did not want children and the honor and security they provided. Whatever the case, Paul did not see it a necessary matter to address, though he addressed a myriad of other marital concerns.

One of the most striking biblical supports for a fulfilling and God-honoring marriage with no children is found in the imagery of Christ and the Church, His bride. Revelation 19:7 says, "Let us be glad and rejoice and give Him glory, for the marriage of the Lamb has come, and His wife has made herself ready." This marriage is referred to elsewhere in the Bible, yet it never includes children in the imagery. Rather, purity, unity, and love are emphasized. Olsen references Augustine's work The Good of Marriage when he says, "The inner reality of marriage parallels that of the Church: the goal is a full joining of spirits in a forgiving love which patiently bears with the other and heals pride and selfishness in mutual service" (Haas et al., 2001, p.121122). Here, Augustine states that marriage itself heals selfishness.

Kurt Burner, on the other hand, claims that the best way to learn unselfishness is through children, and to not want children is in fact selfish (Watters \& Watters, 2009). However, God has many ways to teach His children unselfishness, and though children are certainly one way, they are not the only way. Whatever couples decide, it must be because they feel their decision is the one that will most glorify and honor God. After all, "Whether you eat or drink, or whatever you do [even plan families], do all to the glory of God" (1 Corinthians 10:31). If God leads a couple to not have children, He will provide other means to shape them into the people He wants them to be.

The validity and selflessness of marriage without children is especially evident in couples who want children but are unable to have them. Rather than insist that they adopt or seek reproductive aid, Jill Baughan reminds infertile couples to consider the benefits of having no children. Among other things, she points out that childless couples "could well have more time and stamina to minister to the needs of others as a couple" (1989, p.140). If childlessness from infertility can be condoned, so should the marriages of godly couples who are able but choose not to have children.

In conclusion, the biblical praise of children and parenthood, coupled with the natural and necessary function of reproduction, should make procreation a general goal for most marriages. However, procreation need not be a goal for every marriage, even Christian marriages. Though 
natural, it is not required by God. Rather, each couple should carefully and prayerfully consider what God would have them do. Above all, the goal must be the glory of Christ, and married or single, childless or overflowing with children, each and every Christian must remember Paul's directive. "Let nothing be done through selfish ambition or conceit, but in lowliness of mind let each esteem others better than himself. Let each of you look out not only for his own interests, but also for the interests of others" (Philippians 2:3-4).

\section{Resources}

Baughan, J. (1989). A Hope Deferred: A Couple's Guide to Coping with Infertility. Portland, OR: Multnomah.

Haas, J.M., Hitchcock, J., Martin, F., Olson, G.W., Pierre, T.O., \& Young, R.V. (2001). Christian Marriage: A Historical Study. G.W. Olson (Ed.). New York, NY: The Crossroad Publishing Company.

Köstenberger, A.J. \& Jones, D.W. (2010). God, Marriage, and Family: Rebuilding the Biblical Foundation ( $2^{\text {nd }}$ ed.). Wheaton, IL: Crossway.

Rice, J.R. (1946). The Home: Courtship, Marriage and Children. Wheaton, IL: Sword of the Lord.

Sullivan, D. (2012). Notes from Principles of Bioethics. Cedarville, OH: Cedarville University.

Watters, S. \& Watters, C. (2009). Start Your Family: Inspiration for Having Babies. Chicago, IL: Moody Publishers. 